Journal of Agricultural Sciences
(Tarim Bilimieri Dergisi)

\title{
Assessment of Agricultural Sustainability in Sarikum Lake Basin, Sinop Province, Turkey
}

\author{
Tuba BEŞEN ${ }^{a} \mathbb{D}$, Emine OLHAN ${ }^{b}$ (iD

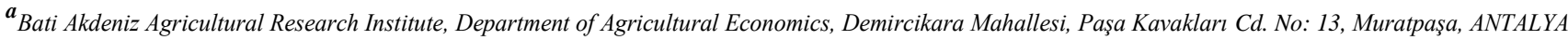

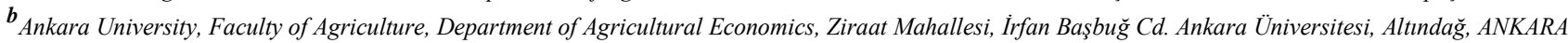

\section{ARTICLE INFO}

Research Article

Corresponding Author: Tuba Beşen, E-mail: tubabesen@ gmail.com

Received: 01 April 2019 / Revised Form: 28 August 2019 / Accepted: 17 September 2019 / Online: 18 January 2021

\section{ABSTRACT}

The sustainability of agriculture in social, economic and environmental dimensions is important in terms of development policies. In this study, agricultural sustainability has been evaluated in social, economic and environmental dimensions. Twenty-one indicators were used and each dimension had 7 indicators. The research was carried out in Sarıkum Lake Basin of Sinop province in Turkey. The information obtained by face-to-face surveys with the farmers and the related statistics were used as data. The index method was used in the evaluation of these data. As a result, agricultural sustainability in the basin was found $13.95 \%$ in the environmental dimension, $9.64 \%$ in the economic dimension and
$16.62 \%$ in the social dimension. The agricultural sustainability in Sarikum Lake Basin was determined as $40.21 \%$. As a result of the study, in order to achieve economic sustainability it is necessary to increase the agricultural income, the ratio of irrigated land and the number of agricultural holdings with sufficient income. In order to ensure social sustainability, it is necessary to establish conditions to prevent migration and to ensure that farmers are satisfied with farming. In order to achieve environmental sustainability, it is necessary to increase the amount of protected area and to reduce wild animal damage.

Keywords: Sustainability; index; indicator; protected area; ecosystem

(C) Ankara University, Faculty of Agriculture

\section{Introduction}

Agricultural ecosystems provide food, feed, bio-energy and pharmaceutical raw materials for human beings and are the basis of human well-being (MEA 2005; Power 2010). It is estimated that the world population would be 9.2 billion in 2050 , which is 7.6 billion in 2018 (WB 2018). Sustainability of agriculture is essential for the continuity of human existence.

Sustainable agriculture is only possible through making whole system sustainable; in social, economic and environmental aspects. The most common method used in the evaluation of sustainability is the index method. When the studies carried out to date were examined, it was observed that studies were carried out not only at the farm level (Gameda et al. 1997; Rigby et al. 2001; Van der Werf \& Petit 2001; Frater \& Franks 2013; Moore et al. 2014; Ryan et al. 2014; Waney et al. 2014), but also at regional, national and global levels (Trisorio 2004; Gomez Limon Jose \& Riesgo 2008; Ceyhan 2010; Vecchione 2010).

The evaluation of agricultural sustainability around protected areas is particularly important in Turkey because of its rich biodiversity. The research area Sarikum Lake Basin, which includes Sarikum Lake Natural Park, has a rich biodiversity, being one of the world bird migration paths and having different ecosystems makes it one of the areas with high natural resource value and these values need to be protected. In addition, these characteristics in the Sarikum Lake basin cause the existing environmental balance to be more fragile.

\section{Material and Methods}

\subsection{Research area}

The research area is located in the Central Black Sea Region, in Sarikum area in the north of Sinop province (Figure 1). The basin has 6773.7 hectares and includes Sarikum, Basaran, Gumussuyu, Tekke, Yenicam, Selbeyi and Incirpinari villages. 


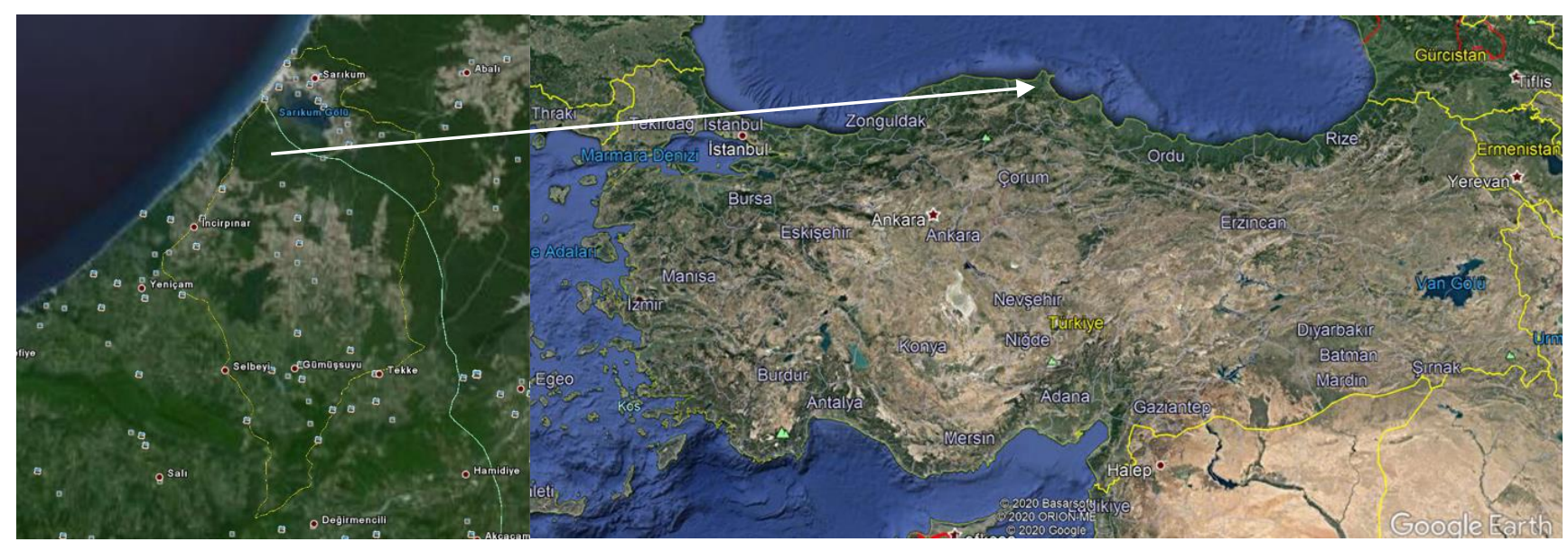

Figure 1- Sarikum Lake Basin

\subsection{Data collection}

The data were collected by face-to-face interviews through surveys with 40 farmers. The survey was conducted 2015 and the data for 2014-2015 production period was compiled. The farmers were selected randomly. The surveys were conducted to identify social, economic and environmental indicators.

\subsection{Computation and data analysis}

The proportional approach was used to determine sample size (Newbold 1995). The number of registered farmers in Erfelek and Merkez districts was 2060. The number of registered farmers in the study area (7 villages) was 413 (MAF 2015). Proportion of farmers in the study area, $\mathrm{p}=0.2$. The sample size was calculated 40 as the proportional sampling was used $90 \%$ confidence interval and $10 \%$ error margin.

$$
n=\frac{N p(1-p)}{(N-1) \sigma_{\hat{p}_{x}}^{2}+p(1-p)}
$$

Where; N, Number of farmer, $\mathrm{p}=$ Proportion of farmers in the study area, variance, $\mathrm{n}, \sigma_{p_{x}}^{2}$ Sample size.

Index method was used to assess agricultural sustainability. The Agricultural Sustainability Index (ASI) of the Sarikum Lake Basin was composed of social, economic and environmental dimensions (Gameda et al. 1997; Petrosyan 2010; Vecchione 2010; Moore et al. 2014; Ryan et al. 2014). The framework of the study was given Figure 2. and ASI steps were given Figure 3. Selecting indicators: In this study, group meetings were conducted in seven villages in the Sarikum Lake Basin before determining the indicators. The indicators were determined in the light of the data obtained from these meetings. The indicators used in this study were site-specific indicators and may not be applied in any another field (Waney et al. 2014). A total of 21 indicators were used in the agricultural sustainability index. Seven indicators were used under each dimension.

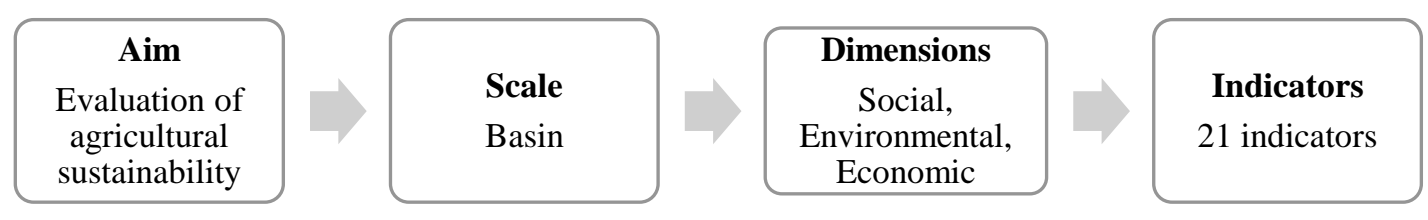

Figure 2- The research framework

Economic Dimension (Gameda et al. 1997; OECD 2002; Petrosyan 2010; Vecchione 2010; Gunduz et al. 2011; Demiryürek et al. 2013; Ryan et al. 2014; Lynch et al. 2019.): 1-Agricultural income competency level (\%): The ratio of farms agricultural income was higher than poverty line. 2-Land productivity: It shows the ratio of farms higher agricultural income per da than average agricultural income per da in the basin.3-Fragmentation of land index: While the high fragmentation level has a positive impact on environmental sustainability, it has a negative impact on the economic dimension (Vecchione 2010). Therefore, Equation 2 was used to evaluate land fragmentation. 4-Crop diversification: Crop diversification decrease risks arising out of economic and environmental conditions (Zulfiqar \& Thapa 2017). Equation 1 used to evaluate crop diversification. 5-Mechanization index: This index indicates a measure technological level of farms. It was the ratio of farms 
with high level of mechanization to all farms (Vechione 2010).6-Land size (\%): Soil Conservation and Land Use Law No. 5403 (Annex: 30/4 / 2014-6537 / article 5) refers to optimum size of farm land in Turkey (TR 2014). The optimum land size was $170 \mathrm{da}$. The ratio of the agricultural holdings have optimum land size. 7-Irrigated land (\%): The ratio of irrigated land to the all land.

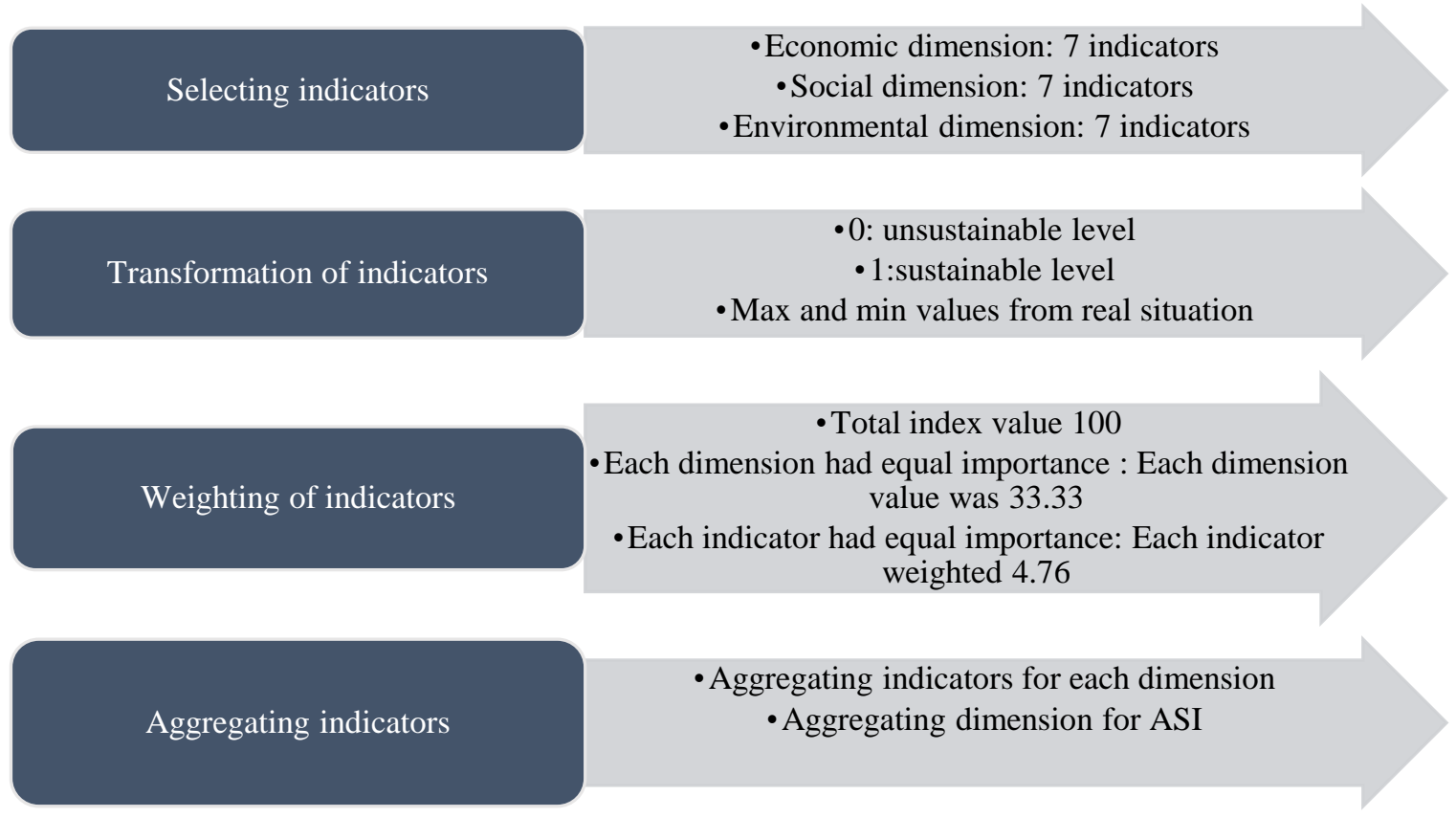

Figure 3- The steps of Agricultural Sustainability Index

Social Dimension (Gameda et al. 1997; OECD 2002; Petrosyan 2010; Vecchione 2010; Gunduz et al. 2011; Demiryürek et al. 2013; Moore et al. 2014; Ryan et al. 2014; Lynch et al. 2019): 1-Farm owner age index: The ratio between the numbers of farm owners with younger than sixty years and the all farm owners (\%). 2-Gender distribution: Measures labour equality (Vecchione 2010). The ratio of female to all population. 3-Population resident: It is the number of residents in a particular geographic area (person/ha) (Vecchione 2010). 4-Organization level (\%): The value was the ratio of the farmers belongs to any association, cooperative, union or professional chamber to the whole farmers. 5-Communication level (\%): It was the ratio between the numbers of farmers who communicate agricultural organizations and the numbers of all farmers. 6-Satisfaction with dealing with agricultural activities (\%): The ratio of farmers that were satisfied with dealing with agricultural activities to the total number of farmers. 7-Level of following agricultural innovations (\%): The ratio of farmers following agricultural innovations to all farmers.

Environmental Dimension (Gameda et al. 1997; OECD 2002; Vecchione 2010; Gunduz et al. 2011; Demiryürek et al. 2013; Moore et al..2014; Ryan et al. 2014; Lynch et al. 2019): 1-Ratio of the farms with erosion problem (\%): The ratio of the farms with erosion problems to the whole farms (Barrera Roldan \& Saldivar Valdes 2002). 2-Use of pesticides (\%): It was the ratio of the farmers using pesticides to all farmers (Zulfiqar \& Thapa 2017). 3-Use of chemical fertilizers (\%): It was the ratio of the farmers using chemical fertilizers to all farmers. 4-Level of soil analysis (\%): The rate of the farms having soil analysis (Zulfiqar \& Thapa 2017). 5-The protected area level (\%): The ratio of the protected area in the total area (Barrera Roldan \& Saldivar Valdes 2002). 6-Farmer's opinion about Sarikum Lake Natural Park as a protected area (\%): The ratio of the farmers who are pleased to existence of protected area. 7-Ratio of wild animal damage (\%): The ratio of the farms under wildlife damage to all farms.

However, it is necessary to consider the dynamics affecting the behavior of the indicators their spatial and temporal characteristics (Zhen \& Routray 2003; Van Pham \& Smith 2014; Mulligan et al. 2016). The second step of the ASI was transformation of the data (Figure 3). In the determination of agricultural sustainability, different approaches have been introduced (Rigby et al. 2001; Sulser et al. 2001; Ceyhan 2010; Petrosyan 2010; Vecchione 2010).

Index $=1-\frac{[\text { Maximum value }]-[X]}{[\text { Maximum value }- \text { Mininmum value }]}$

Index $=1-\frac{[X]-[\text { Maximum value }]}{[\text { Minimum value }- \text { Maximum value }]}$ 
$X=$ The value of the variable used as the indicator (Barrera Roldan \& Saldivar Valdes 2002; Ceyhan 2010; Demiryürek et al. 2013).

The third and fourth step of the ASI was given Figure 3. Each dimension of the ASI (social, economic and environmental dimensions) and each indicator of the ASI (21 indicators) had equal importance to eliminate influences of weights on the results (Figure 3). Each indicator multiplied by 4.76 to give final score out of 100 . Total index value equal to 100 , each dimension value equal to 33.3 and each indicator value equal to 4.76 . These values also represent the max sustainability level (Figure 3).

\section{Results and Discussion}

\subsection{Evaluation of structural characteristics of farms}

Structural characteristics of investigated farms were given in Table 1. Average household size was about 4 . Fifty-five percent of the population was female and $45 \%$ male. Average age of farm owner was 58 and they had about 5 years of education. They had an average of 64.6 da of land. Each farm was made of about five parcels of land, and each parcel was about 13.6 da in size (Table 1). The level of agricultural income adequacy was one of the most important indicators that show economic sustainability of agriculture. The value of this indicator was $1.05 \%$ (Figure 4). Waney et al. (2014) stated that the income was the most important indicator among the indicators determined by farmers. The main economic activity in the basin was agricultural activities. The high agricultural production cost was the most important reason of the low agricultural income level. Dellal et al. (2007) stated that the fuel costs rate in the total cost was varies 10\%-20\%. Land productivity index value determined as $2.00 \%$ (Figure 4). There were several reasons, which declined the land productivity. The production area of the high value-added products was very limited in the basin and family farming was common. Geographic features of the basin were the other factors that decreased the land productivity. Among the most important factors affecting the effective and sustainable use of agricultural land are its scale and fragmentation status. The number of parcels of agricultural land per holding was 5.9 and average parcel size of agricultural land was 12.9 da in 2016 in Turkey (TUIK 2018a). The less fragmentation of agricultural land had positive effect on the agricultural sustainability at economic aspect while it had negative effects at environmental aspect. The land fragmentation index value had the best score with 3.14\% (Figure 4). Increasing the variety of crops in agricultural holdings had positive effects on agricultural sustainability in economic terms. The index of crop diversity was determined as $1.81 \%$ (Figure 4). The positive effect of crop diversity on the agricultural income was not demonstrated in the basin because the ratio of high market value crops was low. The mechanization index value determined as $1.29 \%$ (Figure 4). The low agricultural income level of the basin was the one of the most important reasons decreased the mechanization infrastructure investment. While the optimum farm size for dry conditions is stated as 170 da in Turkey (TR 2014), the average farm size of the Basin was 64,6 da. The number of agricultural holdings that met this condition in the basin was almost negligible and the indicator value was $0.24 \%$ (Figure 4). Türkten et al. (2014) stated that the average agricultural land size per agricultural holdings was 64.4 da in the Black Sea region. Thirty-one percent of the total land in Turkey was irrigated (TUIK 2018b). The rate of irrigated land in the basin was very low with $2.5 \%$ and the index value was the lowest with $0.12 \%$ in the economic dimension indicators of ASI (Figure 4). Due to the Mediterranean climate characteristics of the basin, the long drought period also decreased land efficiency and increased the need for irrigation.

Table 1- Characteristics of investigated farms

\begin{tabular}{lrr}
\hline Characteristics of farms & Mean & Std. Deviation \\
\hline Household size & 3.93 & 1.82 \\
Female & 2.17 & 1.22 \\
Male & 1.76 & 0.89 \\
Age of farm owner (year) & 58.17 & 10.12 \\
Education of farm owner (year) & 5.39 & 1.80 \\
Farm land (da) & 64.61 & 41.90 \\
Number of parcels & 4.76 & 2.93 \\
\hline
\end{tabular}

While assessment of agricultural sustainability, the social dimension has been often neglected because of difficult to measure. There was a need to develop methodologies for the evaluation of the social dynamics (Pinter \& Herren 2006). Young farmers are extremely important roles to promote development in rural areas. It was determined that $78 \%$ of the farm owners was older than 50 years old in the basin. The fact that agricultural activities were based on labor force had increased the importance of young population in agriculture. In addition, wild boar pressure is very high on the agricultural lands in the basin. This situation increased the amount of labor needs in the agricultural holdings. The wild boar damage, the number of labor force and the low level of young population cause increase the amount of uncultivated land that can be forested in a short time. The ratio of female population determined as 55\%. While women were actively involved in agricultural activities, they were not effective in decision-making processes in the agricultural holdings. The women who were actively involved in the production activities in the long term would bring about the fact that they were the decision makers in the business and had a 
positive impact on agricultural sustainability in terms of gender equality. The economic structure of rural areas based on the agriculture and the socio-economic life and developments in these regions were a part of the agriculture. In some studies on rural migration show that factors related to agriculture were considered in the first place among the reasons of rural migration (Guresci 2009). The value of the resident population indicator was determined as $1.43 \%$ (Figure 4). When this indicator was evaluated together with other indicators (age, agricultural income, etc.), it could be foreseen that the resident population would continue to decrease in the basin. The main objective of the organization in agricultural was to increase the productivity of agricultural sector and to improve the producer's income and market position (İnan et al. 2000). Producer organization in the Turkish agriculture sector was not sufficient (MAF 2014). The organization level indicator value determined as $2.43 \%$ (Figure 4). The high level of relationship with agricultural organizations had a positive impact on agricultural sustainability. The index value of this indicator was $2.90 \%$ (Figure 4). The fact that farmers were in close contact with agricultural organizations was also an indicator of their willingness to make more conscious production in the basin, where a high proportion of elderly population and primary education common. The follow-up agricultural innovations showed the willingness to be open to new agricultural techniques and to implement it, and positively affected the agricultural sustainability. The index value of this indicator in the basin was $2.57 \%$ (Figure 4). In order to get positive results from development at local level, human-oriented, egalitarian and inclusive model must be established (Göymen 2004).

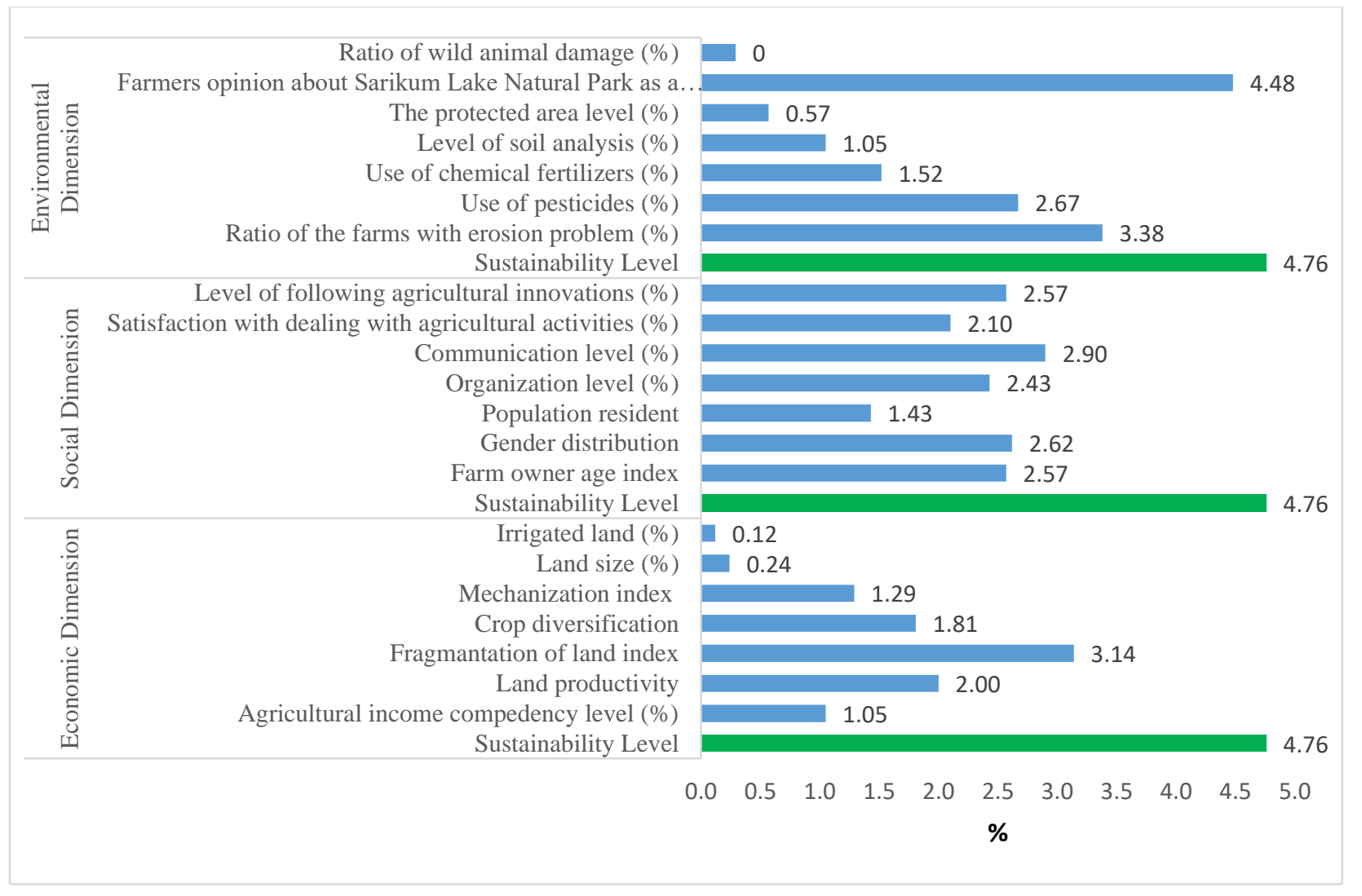

Figure 4- Agricultural sustainability indicators of Sarikum Lake Basin (\%)

Twenty-nine percent of the agricultural holdings in the basin had erosion problems. The index value was 3.38\% (Figure 4). The height of the basin varied between 0-440 meters. While $25.7 \%$ of the land was composed of flat and slightly slope areas, $46.2 \%$ of it is steep and steep slopes. The decrease in erosion risk in agricultural lands increased agricultural sustainability (Beşen et al. 2018). In Turkey, 59\% of the cultivated land, while 64\% of pastureland had erosion (MD 2014). The soil erosion reduced crop yields and increased the costs of production (FAO 2018). Waney et al. (2014) identified that the erosion control and the disease and pest control were the most important indicators at the environmental dimension for farmers. The high number of enterprises using pesticides had a negative impact on agricultural sustainability in the environmental dimension. The index value of the use of pesticides was $2.67 \%$ (Figure 4). The total amount of pesticide used was 54098 tons in 2017 in Turkey (TUIK 2018c). In recent years, biological control methods have more importance. Biological control methods should be supported in order to reduce the use of pesticides in the basin (Portakaldali et al. 2015). Not only pesticide usage but also chemical fertilizer usage in unconsciously in agriculture harms the environment (Ataseven \& Olhan 2010). The index value of chemical fertilizer use was $1.52 \%$ (Figure 4). The total amount of chemical fertilizer used was 13.09 billion tons in 2017 in Turkey (TUIK 2018d). Soil is essential for crop production. Neither food could be produced on a large scale, nor would livestock be fed without soil (FAO 2011). The index value of the soil analyses level was $1.05 \%$ (Figure 4). The rate of those using chemical fertilizers was higher than the rate of those having soil analysis. This indicated that the use of unconscious chemical fertilizers was widespread in the basin. The organic agriculture and the good agricultural practices have been 
supported throughout the world in order to minimize the residues and to ensure sustainable environment (Türkten et al. 2014, MAF 2017). The fact that the Sarikum Lake Basin has a rich biodiversity. The presence of protected areas in the basin affects the agricultural sustainability positively. The index value determined as $0.57 \%$ (Figure 4 ). The more effective protection can be provided by extending the protected area boundaries to the limits of the micro-catchment level. Adoption of protected areas by local people is very important in terms of preserving all natural values. It was determined that the people in the basin were satisfied with the presence of Sarıkum Lake Nature Park. Indicator value was $4.48 \%$ (Figure 4). Having a positive perspective about protected areas is a reflection of the importance given to environmental values. The high number of wild animals in forest areas increases wild animal damage in agricultural production areas and negatively affects agricultural sustainability in economic dimension. Wild animal damage indicator value was determined as $0.29 \%$ (Figure 4). It has the lowest value in the environmental dimension of agricultural sustainability. However, the presence of wild animals is an important source for the biological diversity of the Sarikum Lake Basin and the presence of wild animals in terms of environmental sustainability creates a positive effect. On the other hand, the excessive increase in the population of a species can pose a threat to other species. It is necessary to control the wild boar population in order to protect the balance between the species and to reduce the wild boar damage on agricultural production areas. Solutions need to be developed to prevent conflicts between wildlife and rural populations. Thus, it can be ensured that nature and agriculture become factors that support each other, not competing with each other.

\section{Conclusions}

As a result of the research, economic sustainability had the lowest value while social sustainability had the highest value (Figure 5.) and the agricultural sustainability level of research area determined $40.23 \%$ (Figure 6). This value indicated that if the conditions of the area in social, economic and environmental aspects were not changed, the agricultural activities would be decrease. The sustainability of agriculture must be ensured in order to meet the increasing food demand and to protect all the benefits of agricultural ecosystem services.

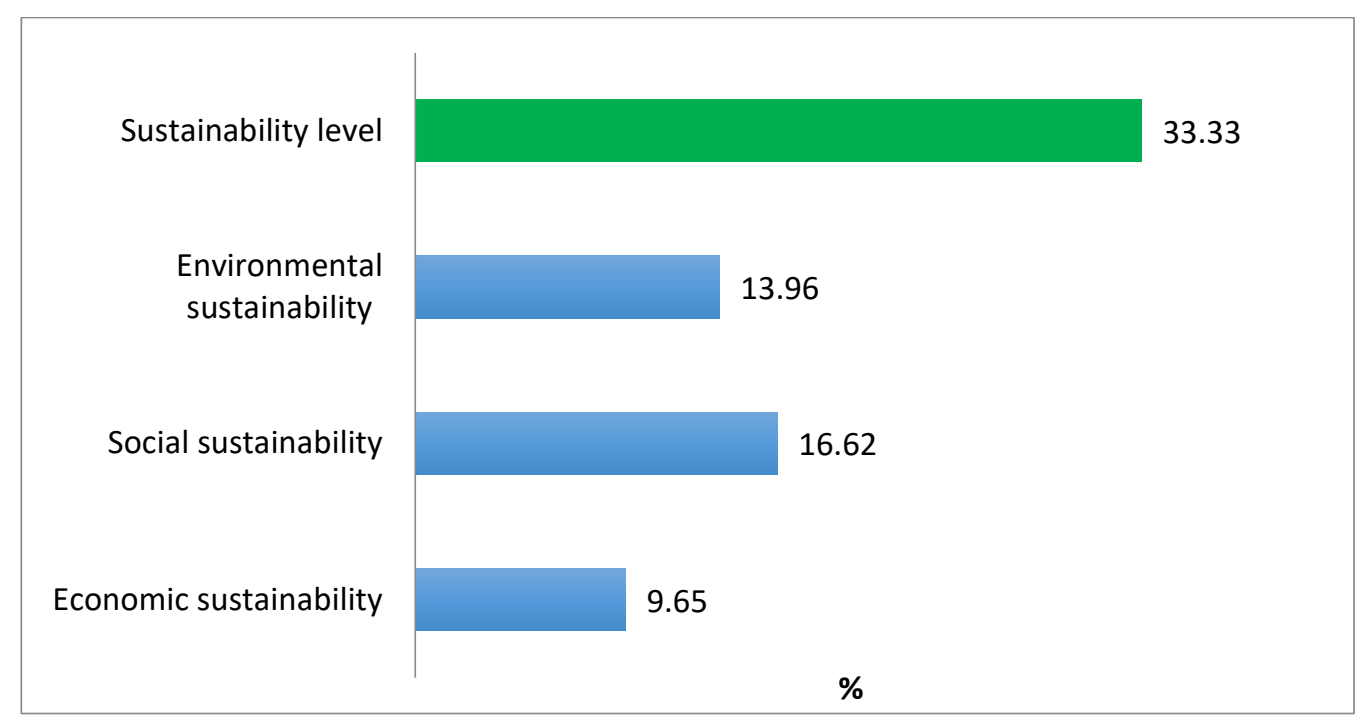

Figure 5- Economic, social and environmental sustainability level of Sarikum Lake Basin (\%)

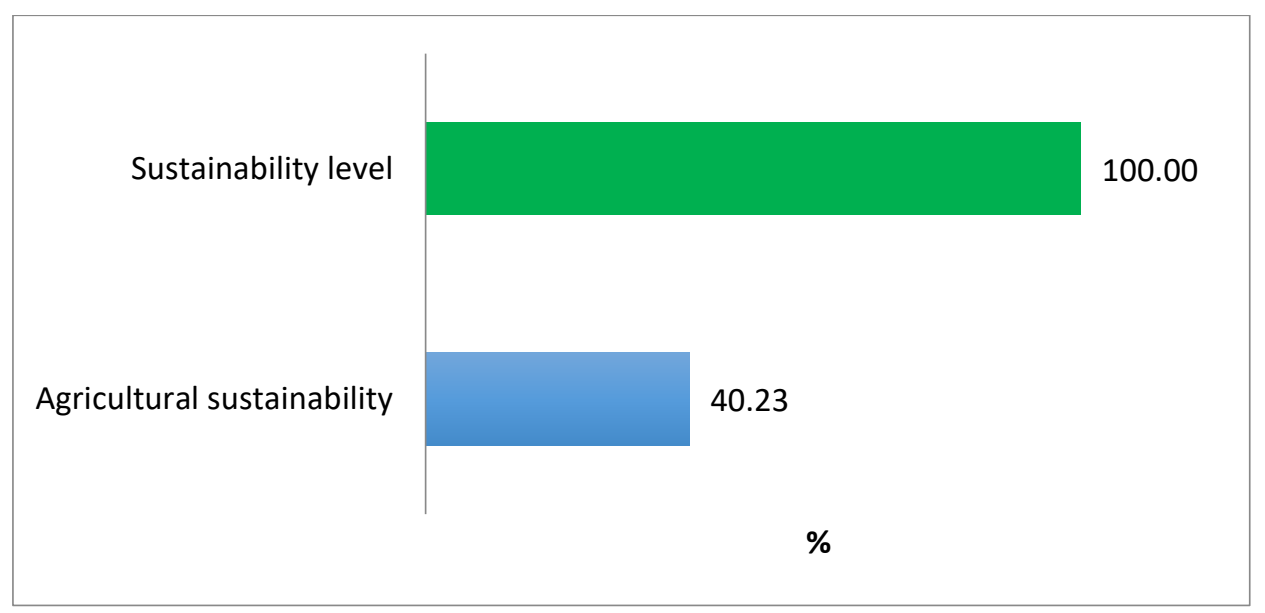

Figure 6- Agricultural sustainability level of Sarikum Lake Basin (\%) 


\section{Acknowledgements}

This work is part of the Assessment of Agricultural Sustainability in Sarikum Lake Basin, Sinop Province, Turkey project financially supported by the Ministry of Agriculture and Forestry. We express our sincerest gratitude to them for their support.

\section{References}

Ataseven Y \& Olhan E (2010). Environmental evaluation of pollutions due to agricultural activities in drinking water basins. Journal of Environmental Protection and Ecology 11(4): 1253-1263

Barrera Roldan A \& Saldivar Valdes A (2002). Proposal and application of a sustainable development index. Ecological Indicators 2(2002): 251-256. https://doi.org/10.1016/S1470-160X(02)00058-4

Beşen T, Karakurt E, Elmas E, Karabulut Aloe A, Sürek D, Aysel Altundağ A, Bay U, Karahan F, Dengiz O, Namlı A, Ateş C, Saygın F, Cebel H, İncirkus V, Demirkıran O \& Başkan O (2018).Developing rural development methodology by ecosystem approach project. (In Turkish). Ankara

Ceyhan V (2010). Assessing the agricultural sustainability of conventional farming systems in Samsun province of Turkey. African Journal of Agricultural Research, 5(13): 1572-1583. https://doi.org/10.5897/AJAR09.434

Dellal İ, Özat H E \& Özüdoğru T (2007). Diesel use in agriculture and diesel support work report (In Turkish). Yayın No: 163, Tarim ve Koy Isleri Bakanligi, Ankara, Turkey

Demiryürek K, Ceyhan V \& Argunhan E (2013). Sustainability of organic and conventional hazelnut breeding activities (In Turkish). In: Proceeding of Turkiye 5. Organik Tarım Sempozyumu. 25 -27 Eylül, Samsun s. 68-73

FAO (2011). Save and grow a policymaker's guide to the sustainable intensification of smallholder crop production. Retrieved in December, 12, 2018 from http://www.fao.org/ag/save-and-grow/en/3/index.html

FAO (2018). Soil erosion. Retrieved in December, 12, 2018 from http://www.fao.org/fileadmin/templates/cpesap/CRESAP_Info_package/Links/Module_4/Soil_erosion.pdf.

Frater P \& Franks J (2013). Measuring agricultural sustainability at the farm level: A pragmatic approach. International Journal of Agricultural Management 2(4): 207-225. ISSN: 2047-3710

Gameda S, Dumanski J \& Acton D (1997). Farm level indicators of sustainable land management for the development of decision support systems. In: Proceeding of the international workshop on geo-information for sustainable land management, Enschede, The Netherlands

Gomez Limon Jose A \& Riesgo L (2008). Alternative Approaches on Constructing a Composite Indicator to Measure Agricultural Sustainability. In: Proceeding EAAE Seminar "Modelling of Agricultural and Rural Development Policies, Sevilla, Spain

Göymen K (2004). Municipalities as Local Development Leaders and Stakeholders (In Turkish). Retrieved in August 2, 2016 from https://research.sabanciuniv.edu/1427/1,korelGoymen.pdf

Gunduz O, Ceyhan V, Erol E \& Ozkaman F (2011). An evaluation of farm level sustainability of apricot farms in Malatya province of Turkey. Journal of Food, Agriculture \& Environment 1. 9(1): 700-705. https://doi.org/10.1234/4.2011.2037

Guresci E (2009). The relationship between rural migration and agricultural policy (In Turkish). Muğla Üniversitesi, Sosyal Bilimler Enstitüsü Dergisi. 22(2009): 51-67

İnan İ H, Gülçubuk B, Ertuğrul C, Kanturer E, Baran E A \& Dilmen O (2000). Rural Organization in Agriculture (In Turkish). In: Türkiye Ziraat Mühendisliği 5.Teknik Kongresi, TMMOB-ZMO, 17-21 Ocak, Ankara

Lynch J, Donellan T, Finn J A, Dillon E \& Ryan M (2019). Potential development of Irish agricultural sustainability indicators for current and future policy evaluation needs. Journal of Environmental Management, 230 (2019): 434-445

MAF (2014). Ulusal kırsal kalkınma stratejisi 2014-2020 The Republic of Turkey, Ministry of Agriculture and Forestry

MAF (2015). The Farmer Registry System database. The Republic of Turkey, Ministry of Agriculture and Forestry

MAF (2017). Ministry of Agriculture and Forestry. Retrieved in February, 2, 2017 from https://www.tarimorman.gov.tr

MD (2014). Onuncu Kalkınma Planı 2014-2018, Tarım Özel İhtisas Komiyonu, Tarım Arazilerinin Sürdürülebilir Kullanımı Çalışma Grubu Raporu. ISBN:9786054667581, Ankara. TR Ministry of Development

MEA (2005). A Report of the millennium ecosystem assessment, ecosystems and human well-being. Island Press, Washington DC

Moore A, Dormody T, Van Leeuwen D \& Harder A (2014). Agricultural sustainability of small - scale farms in Lacluta, Timor Leste. International Journal of Agricultural Sustainability 12(2): 130-145. doi:10.1080/14735903.842341

Mulligan M, Burke S \& Ogilvie A (2016) Much More than Simply "Desertification": Understanding Agricultural Sustainability and Change in the Mediterranean. In: Behnke R, Mortimore M. (eds) The End of Desertification? Springer Earth System Sciences. Springer, Berlin, Heidelberg

Newbold P (1995). Statistics for Business and Economics, Prentice-Hall, New Jersey

OECD (2002). Aggregated environmental indices review of aggregation methodologies in use. Working group on environmental information and outlooks. Environment Directorate Environment Policy Committee. OECD. Env,epoc/Se (2001)2,final

Petrosyan A (2010). A model for incorporated measurement of sustainable development comprising remote sensing data and using the concept of biodiversity. Journal of Sustainable Development, 3(2): 9-26 https://doi.org/10.5539/jsd.v3n2p9

Pinter L \& Herren H R (2006). From common principles to common practice. In: Proceedings and outputs of the first Symposium of the International Forum on Assessing Sustainability in Agriculture (INFASA), March 16, 2006, Bern, Switzerland

Portakaldalı M, Öztemiz S, Yarpuzlu F, Karut S \& Eymirli S (2015). Biological Control (In Turkish). Tarımsal Araştırmalardan Bakış. Retrieved in December, 10, 2016 from http://www.tepge.gov.tr/Dosyalar/Yayinlar/603d80dcde4d499cb6d7c82bae18b025.pdf

Power A G (2010). Ecosystem services and agriculture: tradeoffs and synergies, Philosophical Transactions of the Royal Society B: Biological Sciences 365(1554): 2959-2971. https://doi.org/10.1098/rstb.2010.0143

Rigby D, Woodhouse P, Young T \& Burton M (2001). Constructing a farm level indicator of sustainable agricultural practice. Ecological Economics, 39 (2001): 463-478. https://doi.org/10.1016/S0921-8009(01)00245-2

Ryan M, Hennessy T, Buckley C, Dillon E, Donnellan T, Hanrahan K \& Moran B (2014). The development of farm level sustainability indicators for Ireland using the Teagasc National Farm Survey. Paper prepared for presentation at the $88^{\text {th }}$ Annual Conference of the Agricultural Economics Society. Paris 
Sulser T B, Duryea M L, Frolich L M \& Guevara-Cuaspud E (2001). A field practical approach for assessing biophysical sustainability of alternative agricultural systems. Agricultural Systems 68 (2): 113-135. https://doi.org/10.1016/S0308-521X(01)00003-8

Trisorio A (2004). Quantitative assessment and measure of sustainability. Indicators for Italian agriculture. Workshop 1Agriculture, Development of core elements of integrated sustainability scenarios for agriculture (Goal definition and Pre-Backcasting). Florence, 1920 October, Italy

TR (2014). Turkish Republic, Law No. 5403 Soil preservation and land utilization. Retrieved in October, 20 , 2015 from http://www.resmigazete.gov.tr/eskiler/2014/05/20140515-1.htm

Türkten H, Aydın Eryılmaz G, Ceyhan V \& K1lıç O (2014). Evaluation of Environmentally Aimed Agricultural Land Conservation Program in Bafra District and Sustainability of the Effects of Good Agricultural Practices (In Turkish). XI. Ulusal Tarım Ekonomisi Kongresi, 3-5 Eylül, Samsun

TUIK (2018a) Retrieved in October, 17, 2018 from http://www.tuik.gov.tr/PreIstatistikTablo.do?istab_id=2745

TUIK (2018b) Retrieved in October, 17, 2018 from http://www.tuik.gov.tr/PreIstatistikTablo.do?istab_id=2743

TUIK (2018c) Retrieved in October, 17, 2018 from http://www.tuik.gov.tr/PreIstatistikTablo.do?istab_id=2288

TUIK (2018d) Retrieved in October, 17, 2018 from http://www.tuik.gov.tr/PreIstatistikTablo.do?istab_id=2287

Van der Werf H M G \& Petit J (2001). Evaluation of the environmental impact of agriculture at the farm level: A comparison and analysis of 12 indicator - based methods. Agriculture, Ecosystems and Environment 93 (2002): 132-145

Van Pham L \& Smith C (2014). Drivers of agricultural sustainability in developing countries: a review. Environment Systems and Decisions, 34(2): 326-341. https://doi.org/10.1007/s10669-014-9494-5

Vecchione G (2010). EU rural policy: Proposal and application of an agricultural sustainability index. Munich Personel RePec Archive. Retrieved in October, 5, 2015 from https://mpra.ub.uni-muenchen.de/27032/

Waney N F L, Soemarno, Yuliaty Y, Polli B (2014). Developing indicators of sustainable agriculture at farm level. Journal of Agriculture and Veterinary Science, 7 (2): $42-53$ www.iosrjpurnals.org

WB (2018). Population estimates and projections. Retrieved in December, 28, 2018 from http://databank.worldbank.org/data/source/population-estimates-and-projections\#

Zhen L \& Routray J K (2003). Operational indicators for measuring agricultural sustainability in developing countries. Environmental Management, 32(1): 34-46. https://doi.org/10.1007/s00267-003-2881-1

Zulfiqar F \& Thapa G B (2017). Agricultural sustainability assessment at provincial level in Pakistan. Land Use Policy 68(2017): 492-502.

https://doi.org/10.1016/j.landusepol.2017.08.016 